\title{
ADVENTIZATION OF DENDRFLORA OF THE OREL RIVER VALLEY (UKRAINE)
}

\author{
Ivanko Iryna*, Gorban Vadym \\ Oles Honchar Dnipro National University, Dnipro, Ukraine \\ Received 25. 6. 2017 \\ Revised 28. 6. 2017 \\ Published 27.11.2017
}

The purpose of our study is to establish the features of the adventization of the flora of trees and shrubs in the valley of the Orel River. As a result of geobotanical studies it was established that the tree-shrub vegetation in the valley of the river. The eagle is represented by natural forests, artificial plantations and semi-natural plantations, among which natural forests of oak (Quercus robur) and artificial plantations of pine-tree (Pinus sylvestris) and black locust (Robinia pseudoacacia) are predominant. It was revealed that within the taxonomic composition of the dendroflora of the valley of the Orel River (95 woody and shrubby species) the adventive fraction consists of 33 species (35\%), which belong to 18 families. Within the area studied, 17 species were naturalized into the adventitious fractions of dendroflora. By origin in the adventive fraction of dendroflora the species with Asian (10 species - 30\%) and North American (10 species $-30 \%$ ) primary areas predominate. Other microelements are represented by single species and 4 species - with an unidentified primary area (anecophytes). Six woody-shrubby species show invasive activity in phytocenoses of the valley of the Orel River. They are invasive neophytes: Robinia pseudoacacia L., Acer negundo L., Ulmus pumila L., Elaeagnus angustifolia L., Amorpha fruticosa L., Partenocissus quinquefolia (L.) Planch. Now they are naturalized and actively infect various types of biotopes: the coastal zones of the Orel River and its tributaries, beams, natural and artificial forests, and more recently - lands that are withdrawn from agricultural use. The intensive adventitization of the dendroflora of the valley of the Orel river was discovered. It shows the anthropogenic transformation of this territory. The introduced neophytes have recently been actively naturalized and are the part of the natural phytocoenosis, changing their structure, which poses a threat to natural biodiversity. This requires further monitoring studies of the state of the flora of this territory, as well as observations of naturalization processes and the build-up of the invasive ability of adventive species.

Keywords: adventisation; naturalization; invasive activity; anthropogenic transformation

\section{Introduction}

The problem of adventitization of flora in the modern period is one of the most urgent and acquires a global scale, as it leads to their unification and transformation of the structure. Invasion of alien species can cause significant loss of natural biological diversity and even cause economic damage and pose a danger to human health. In this connection, the advective fractions of flora and the trends in the naturalization and invasive activity of adventitious species in the modern period are carefully analyzed by researchers from different countries (Baranovsky, 1998; Richardson et al., 2000;

*Corresponding author: Iryna Ivanko, Oles Honchar Dnipro National University, Dnipro, Ukraine, $\triangle$ ivanko_ndi_biol_dnu@i.ua 
Protopopova et al., 2002; Pyśek et al, 2012; Baranovski et al., 2016; Berg et al., 2016; Gudžinskas et al., 2016; Sadlo et al., 2017).

In the modern period, it is believed that the expansion of plant areas and the increased invasive ability of adventitious species in virtually all regions of the world are the consequences of years of anthropogenic pressure and global climate change (Protopopova et al., 2007; Walter et al., 2009; Fuentes, 2015; Lykholat et al., 2017). A significant number of naturalized and invasive adventitious species in new areas for themselves under favorable conditions go through the path: introduction - naturalization - invasiveness (INIC) (Pyśek et al, 2012). This is especially true of woody and shrubby adventitive species, which almost all were once introduced, that is, they belong to the ergasophytes.

\section{Materials and methodology}

Route geobotanical studies of woody-shrubby groupings of the valley of the river Orel were held in 2015. The names of species are given according to the modern Ukrainian nomenclature editions (Mosyakin and Fedoronchuk, 1999). The adventitious status and primary area (migraine) are determined on the basis of scientific papers (Protopopova, 1991, 2002; Pyšek et al., 2012). The degree of naturalization of species and invasive activity are given exclusively for the area of research based on their own observations.

\section{Results and discussion}

Tree and shrub vegetation in the valley of the Orel River is represented by natural forests, artificial plantations and semi-natural groupings that do not create a continuous vegetation cover, but have a fragmentary nature of location. This is due to the anthropogenic impact and salinization of the soils of the valley of the river Orel, which limits the development of woody and shrubby vegetation. Among the woody-shrubby groupings of the valley of the river the eagle is dominated by natural forests of oak (Quercus robur L.) and artificial plantations of pine-tree (Pinus sylvestris L.) and black locust (Robinia pseudoacacia L.) are predominant.

According to previous studies, the taxonomic composition of the dendroflora of the valley of the Orel River includes 95 woody (23 species) and shrubby (10) species (Baranovsky et al., 2017). In this case, the adventive fraction consists of 33 species (35\%) belonging to 18 families (Table 1). The predominant families that have the highest species saturation are: Rosaceae - 7 species (21\%), Salicaceae - 4 (12\%) and Fabaceae -3 (9\%).

By origin in the adventive fraction of dendroflora species with Asian (10 species - 30\%) and North American (10 species - 30\%) primary areas predominate. Other microelements are represented by single species and 4 species - with an unidentified primary area (anecophytes).

Within the investigated territory, 17 species (52\%) were naturalized into the adventitious fractions of dendroflora, $82 \%$ of neophytes (14 species) and $18 \%$ of archeophytes ( 3 species). The participation of casual species is $48 \%$ (16 species), of which $88 \%$ are neophytes (14 species) and $12 \%$ archeophytes (2).

Among the naturalized species, species with North American and Asian primary ranges are dominant $-41 \%$ (7 species) and $35 \%(6)$, respectively. 
Table 1 The adventive fraction of tree and shrub vegetation

\begin{tabular}{|c|c|c|c|c|c|c|}
\hline \multirow[t]{2}{*}{ Species within the family boundaries } & \multicolumn{4}{|c|}{ Naturalized / Invasive } & \multicolumn{2}{|c|}{ Casual } \\
\hline & 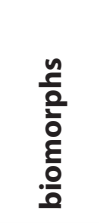 & 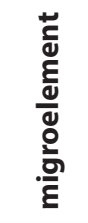 & 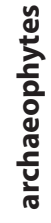 & 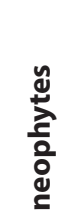 & 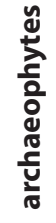 & 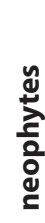 \\
\hline 1 & 2 & 3 & 4 & 5 & 6 & 7 \\
\hline $\begin{array}{l}\text { Pinaceae } \\
\text { Pinus pallasiana D. Don }\end{array}$ & Arb & MIT & - & - & - & + \\
\hline $\begin{array}{l}\text { Aceraceae } \\
\text { Acer negundo L. } \\
\text { Acer pseudoplatanus L. }\end{array}$ & $\begin{array}{l}\text { Arb } \\
\text { Arb }\end{array}$ & $\begin{array}{c}\text { NA } \\
\mathrm{E}\end{array}$ & $\begin{array}{l}- \\
-\end{array}$ & $\begin{array}{c}+/+ \\
-\end{array}$ & $\begin{array}{l}- \\
-\end{array}$ & $\begin{array}{l}- \\
+\end{array}$ \\
\hline $\begin{array}{l}\text { Anacardiaceae } \\
\text { Cotinus coggygria Scop. }\end{array}$ & $\mathrm{Fr}$ & $M$ & - & + & - & - \\
\hline $\begin{array}{l}\text { Caesalpiniaceae } \\
\text { Gleditsia triacanthos } \mathrm{L} \text {. }\end{array}$ & Arb & NA & - & + & - & - \\
\hline $\begin{array}{l}\text { Caprifoliaceae } \\
\text { Lonicera tatarica L. } \\
\text { Sambucus racemosa L. }\end{array}$ & $\begin{array}{l}\mathrm{Fr} \\
\mathrm{Fr}\end{array}$ & $\begin{array}{l}\text { As } \\
E\end{array}$ & $\begin{array}{l}- \\
-\end{array}$ & $\begin{array}{l}- \\
+\end{array}$ & $\begin{array}{l}- \\
-\end{array}$ & $\begin{array}{l}+ \\
-\end{array}$ \\
\hline $\begin{array}{l}\text { Elaeagnaceae } \\
\text { Elaeagnus angustifolia L. } \\
\text { Hippophae rhamnoides L. }\end{array}$ & $\begin{array}{l}\text { FrArb } \\
\text { ArbFr }\end{array}$ & $\begin{array}{c}M \\
\text { EAs }\end{array}$ & $\begin{array}{l}- \\
-\end{array}$ & $\begin{array}{c}+/+ \\
-\end{array}$ & $\begin{array}{l}- \\
-\end{array}$ & $\begin{array}{l}- \\
+\end{array}$ \\
\hline $\begin{array}{l}\text { Fabaceae } \\
\text { Amorpha fruticosa L. } \\
\text { Caragana arborescens Lam } \\
\text { Robinia pseudoacacia L. }\end{array}$ & $\begin{array}{c}\mathrm{Fr} \\
\mathrm{Fr} \\
\mathrm{Arb}\end{array}$ & $\begin{array}{l}\text { NA } \\
\text { As } \\
\text { NA }\end{array}$ & $\begin{array}{l}- \\
- \\
-\end{array}$ & $\begin{array}{c}+/+ \\
+ \\
+/+\end{array}$ & $\begin{array}{l}- \\
- \\
-\end{array}$ & $\begin{array}{l}- \\
- \\
-\end{array}$ \\
\hline $\begin{array}{l}\text { Grossulariaceae } \\
\text { Ribes aureum Pursh }\end{array}$ & $\mathrm{Fr}$ & NA & - & - & - & + \\
\hline $\begin{array}{l}\text { Juglandaceae } \\
\text { Juglans regia L. }\end{array}$ & Arb & MAs & - & + & - & - \\
\hline $\begin{array}{l}\text { Moraceae } \\
\text { Morus alba L. }\end{array}$ & Arb & As & + & - & - & - \\
\hline $\begin{array}{l}\text { Oleaceae } \\
\text { Fraxinus lanceolata Borkh. }\end{array}$ & Arb & NA & - & + & - & - \\
\hline $\begin{array}{l}\text { Rosaceae } \\
\text { Armeniaca vulgaris Lam. } \\
\text { Cerasus mahaleb (L.) Mill. } \\
\text { Cerasus tomentosa (Tumb.) Wall. } \\
\text { Cerasus vulgaris Mill. } \\
\text { Malus domestica Borkh. } \\
\text { Padus serotina (Ehrh.) Ag. } \\
\text { Prunus domestica L. }\end{array}$ & $\begin{array}{c}\text { Arb } \\
\text { FrArb } \\
\text { Fr } \\
\text { Arb } \\
\text { Arb } \\
\text { Arb } \\
\text { Arb }\end{array}$ & $\begin{array}{c}\text { Anec } \\
\text { As } \\
\text { As } \\
\text { Anec } \\
\text { Anec } \\
\text { NA } \\
\text { Anec }\end{array}$ & $\begin{array}{l}- \\
- \\
- \\
- \\
- \\
- \\
-\end{array}$ & $\begin{array}{l}- \\
- \\
- \\
- \\
- \\
+ \\
-\end{array}$ & $\begin{array}{l}- \\
- \\
- \\
+ \\
+ \\
- \\
-\end{array}$ & $\begin{array}{l}+ \\
+ \\
+ \\
- \\
- \\
- \\
+\end{array}$ \\
\hline
\end{tabular}




\section{Continue the Table 1}

\begin{tabular}{|c|c|c|c|c|c|c|}
\hline \multirow[t]{2}{*}{ Species within the family boundaries } & \multicolumn{4}{|c|}{ Naturalized / Invasive } & \multicolumn{2}{|c|}{ Casual } \\
\hline & 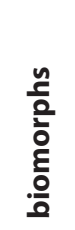 & 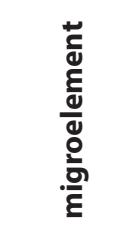 & 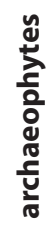 & 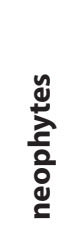 & 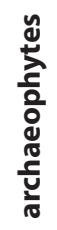 & 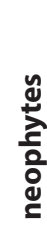 \\
\hline 1 & 2 & 3 & 4 & 5 & 6 & 7 \\
\hline $\begin{array}{l}\text { Salicaceae } \\
\text { Populus deltoides Marsh. } \\
\text { Populus } \times \text { canadensis Moench } \\
\text { Populus italica (Du Roi) Moench } \\
\text { Salix fragilis L. }\end{array}$ & $\begin{array}{l}\text { Arb } \\
\text { Arb } \\
\text { Arb } \\
\text { Arb }\end{array}$ & $\begin{array}{c}\text { NA } \\
\text { NA/Hybr. } \\
\text { As } \\
\text { As }\end{array}$ & $\begin{array}{l}- \\
- \\
- \\
+\end{array}$ & $\begin{array}{l}- \\
- \\
- \\
-\end{array}$ & $\begin{array}{l}- \\
- \\
- \\
-\end{array}$ & $\begin{array}{l}+ \\
+ \\
+ \\
-\end{array}$ \\
\hline $\begin{array}{l}\text { Simarubaceae } \\
\text { Ailanthus altissima (Mill.) Swingle }\end{array}$ & Arb & As & - & + & - & - \\
\hline $\begin{array}{l}\text { Solanaceae } \\
\text { Lycium barbatum L. }\end{array}$ & $\mathrm{Fr}$ & As & + & - & - & - \\
\hline $\begin{array}{l}\text { Tiliaceae } \\
\text { Tilia platyphyllos Scop. }\end{array}$ & Arb & $\mathrm{E}$ & - & - & - & + \\
\hline $\begin{array}{l}\text { Ulmaceae } \\
\text { Celtis occidentalis } \mathrm{L} \text {. } \\
\text { Ulmus pumila } \mathrm{L} \text {. }\end{array}$ & $\begin{array}{l}\text { Arb } \\
\text { Arb }\end{array}$ & $\begin{array}{l}\text { NA } \\
\text { As }\end{array}$ & $\begin{array}{l}- \\
-\end{array}$ & $\begin{array}{c}- \\
+/+\end{array}$ & $\begin{array}{l}- \\
-\end{array}$ & $\begin{array}{l}+ \\
-\end{array}$ \\
\hline $\begin{array}{l}\text { Vitaceae } \\
\text { Partenocissus quinquefolia (L.) Planch. }\end{array}$ & $\mathrm{Fr}$ & NA & - & $+/+$ & - & - \\
\hline
\end{tabular}

Fr (Frutex) - bush; Arb (Arbor) - tree. Migroelement (primary area): As - Asian; E - European; M - Mediterranean; NA - North American; IT - Iranoturan; Anec - anecophytes

Six woody-shrubby species show invasive activity in phytocenoses of the valley of the Orel River. They are exhibited by the invasive neophytes: Robinia pseudoacacia, Acer negundo, Ulmus pumila, Elaeagnus angustifolia, Amorpha fruticosa, Partenocissus quinquefolia. Now they are naturalized and actively infect various types of biotopes: the coastal zones of the Orel River and its tributaries, beams, natural and artificial forests, and more recently - lands that are withdrawn from agricultural use. According to recent studies, active processes of naturalization of such neophytes as Padus serotina, Cotinus coggygria and Celtis occidentalis, recorded for natural and artificial forests. These species are included in the checklist of the adventive species of the Dnipropetrovsk region (Baranovski et al., 2016).

\section{Conclusions}

Significant adventization of the dendroflora of the valley of the Orel River shows the anthropogenic transformation of this territory. The introduced neophytes have recently been actively naturalized and are part of the natural phytocoenosis, changing their structure, which poses a threat to natural biodiversity. This requires further monitoring studies of the state of the flora of this territory, as well as observations of naturalization processes and the build-up of the invasive ability of adventive species. 


\section{References}

Baranovski, B., Khromykh, N., Karmyzova, L., Ivanko, I., Lykholat, Y. 2016. Analysis of the alien flora of Dnipropetrovsk Province. Biological Bulletin of Bogdan Chmelnitskiy Melitopol State Pedagogical University, vol. 6, no. 3, p. 419-429. DOl: http://dx.doi.org/10.15421/2016113

Baranovsky, B.A. 1998. Distribution of shrub amorph in the Dnieper floodplain in cascade conditions. Questions of steppe forest management and land reclamation, p. 147-151.

Baranovsky, B.O., Manyuk V.V., Ivanko I.A., Karmyzova L.A. 2017. Analysis of the flora of the Orilsky National Natural Park. Lira. 320 p. ISBN 978-966-383-875-5.

Berg, C., Drescher, A., Wagner, V., Essl, F., Berg, C. 2016. Temporal trends in the invasions of Austrian woodlands by alien trees. Preslia, vol. 88, p. 185-200.

Fuentes, N., Saldaña, A., Kühn, I., Klotz, S. 2015. Climatic and socio-economic factors determine the level of invasion by alien plants in Chile. Plant Ecology \& Diversity, vol. 8, no. 3, p. 371-377. DOI: 10.1080/17550874.2014.984003

Gudžinskas, Z., Petrulaitis, L. 2016. New alien plant species recorded in the southern regions of Latvia. Botanica Lithuanica, vol. 22, no. 2, p. 153-160. DOI: 10.1515/botlit-2016-0016

Lykholat, Y.V., Khromykh, N.A., Ivan'ko, I.A., Matyukha, V.L., Kravets, S.S., Didur, O.O., Alexeyeva, A.A., Shupranova, L.V. 2017. Assessment and prediction of the invasiveness of some alien plants in conditions of climate change in the steppe Dnieper region. Biosystems Diversity, vol. 25, no. 1, p. 52-59. DOI: 10.15421/011.

Mosyakin, S.L., Fedoronchuk, M.M. 1999. Vascular plants of Ukraine (a nomenclatural checklist). Naukova Dumka. 345 p. ISBN 966-02-1336-0.

Protopopova, V.V. 1991. The synanthropic flora of Ukraine and the ways of its development. Naukova Dumka. 204 p. ISBN 5-12-001943-9.

Protopopova, V.V., Mosyakin, S.L., Shevera, M.V. 2002. Phytoinvasions in Ukraine as a threat to biodiversity: the present state and tasks for the future. M.G. Kholodny Institute of Botany of NAS of Ukraine. 28 p. ISBN 966-02-2763-9.

Protopopova, V.V., Shevera, M.V.2007.Types of adventitious plants of Ukraine as indicators of xerophilization of flora. Materials of the seminar in relation to the approval of the National report on the implementation of the UN Convention on the combating of desertification in Ukraine. Kiev, p. 79-85.

Pyšek, P., Danihelka, J., Sádlo, J., Chrtek, J. Jr., Chytrý, M., Jarošík, V., Kaplan, Z., Krahulec, F., Moravcová, L., Pergl, J., Štajerová, K., Tichý, L. 2012. Catalogue of alien plants of the Czech Republic (2 ${ }^{\text {nd }}$ edition): Checklist update, taxonomic diversity and invasion patterns. Preslia, vol. 84, p. 155-255.

Richardson, D.M., Pyśek, P., Redjmanek, M., Barbour, N.G., Panetta, F.D., West, S. J. 2000. Naturalization and invasion of alien plants: concepts and definitions. Diversity \& Distributions, vol. 6, p. 93-107. DOI: 10.1046/j.1472-4642.2000.00083.x

Sadlo, J., Vitkova, M., Pergl, J., Pyšek, P. 2017. Towards site-specific management of invasive alien trees based on the assessment of their impacts: the case of Robinia pseudoacacia. NeoBiota, vol. 35, p. 1-34. DOI: $10.3897 /$ neobiota.35.11909

Walther, G.-R., Roques, A., Hulme, P.E., Sykes, M.T., Pyšek, P., Kühn, I., Zobel, M., Bacher, S., Botta Dukát, Z., Bugmann, H., Czúcz, B., Dauber, J., Hickler, T., Jarosík, V., Kenis, M., Klotz, S., Minchin, D., Moora, M., Nentwig, W., Ott, J., Panov, V.E., Reineking, B., Robinet, C., Semenchenko, V., Solarz, W., Thuiller, W., Vilà, M., Vohland, K., Settele, J. 2009. Alien species in a warmer world: risks and opportunities. Trends in Ecology and Evolution, vol. 24, no. 12, p. 686-693. DOI: 10.1016/j.tree.2009.06.008 